\title{
Plants from the Upper Old Red Sandstone of Slieve Bloom, County Oftaly, Eire
}

\author{
(Plate 1)
}

SIR - Hugh Miller's remarks upon the scant nature of our knowledge of the flora of the Old Red Sandstone are scarcely in need of revision today; more than a century later a worker adding even a slight increment to that knowledge may presume upon tolerance in his readers of 'the comparative meagreness of the few remarks' which he may be able to make, since even today 'that meagreness is only too representative of the present state of our knowledge regarding them; and if his descriptions be scanty and inadequate it is only because the facts are still few' (Miller, 1857). The list of fossil plants from the Upper Devonian-Lower Carboniferous Old Red Sandstone of Ireland is very short indeed, and accordingly new records of good material take on a somewhat increased importance, however meagre it may seem in comparison with the splendid museums of material of the same age from such places as North America and the U.S.S.R.

Several beautifully preserved leaflets, together with numerous indeterminate stem fragments, have been discovered towards the top of the Old Red Sandstone near Kinnitty in north-western Slieve Bloom during recent work on the Lower Palaeozoic and Old Red Sandstone rocks of this area. Wynne had previously recorded a single leaflet and numerous stem fragments in south-western Slieve Bloom, in the townland of Ballyduff along the River Bunnow, and these were described and figured by Baily in O'Kelly's Memoir (O'Kelly, 1862); Baily considered the leaf to resemble 'a species of Sphenopteris'.

The Old Red Sandstone of north-western Slieve Bloom comprises some $300 \mathrm{~m}$ of predominantly yellow sandstones, with some red siltstones and rare conglomerates. The fossiliferous sequence near Kinnitty comprises grey silty mudstones, of ten micaceous, with wavy lamination in some horizons. These beds attain a maximum thickness of about $70 \mathrm{~cm}$, and the fossils are confined to a small number of bedding planes within it. These lithologies may have originated in a coastal plain flood basin of the type described by Russell (1967), closed at its downstream end and thus waterlogged and swampy, with shallow lakes in which plant debris and thick deposits of clay could be laid down. Such conditions are likely to have prevailed just before the Lower Carboniferous transgression. The split cuneate leaflets of several of the specimens exhibit a form common in a number of Upper Devonian and Carboniferous genera. Others show a pinnate structure of Sphenopteris type. All the material closely resembles Aneimites acadica Dawson, 1860, which is best seen in the shales of the Horton Group below the Lower Carboniferous marine limestones in the lower Coal Measures of eastern North America (Dawson, 1866, 1873). The species has been described more recently by Bell (1960), and is cited by Boureau (1975) as a synonym of $A$. obtusilobus (Naumann) Ettingshausen, 1865; the Slieve Bloom material is accordingly assigned tentatively to this taxon, although Chaloner (pers. comm.) doubts if a secure and useful specific name can be given to it. The material also resembles Adiantites spectabilis (Read, 1965), which Bell (1960) considered to be simply a form of Aneimites acadica.

Johnson's work on the conodont microfauna of the Lower Limestone Shale at Cadamstown (unpubl. thesis, . Univ. of Dublin), which is dominated by Polygnathus inornatus, shows the rocks to be of Tournaisian Zone 2 age. The uppermost Old Red Sandstone is thus probably Courceyan in age. The occurrence of Aneimites obtusilobus towards the top of the Old Red Sandstone both at Ballyduff and near Kinnitty is consistent with this interpretation. Projected work on the plant microfossils may enable more precise dating of the plant-bearing shales near Kinnitty.

The work on north-western Slieve Bloom was carried out under the supervision of Professor C. H. Holland, whose comments and criticism are gratefully acknowledged; the assistance of Dr D. G. Smith and $\mathrm{Mr} \mathrm{J}$. Cuffe is also acknowledged.

\section{References}

Bell, W. A. 1960. Mississipian Horton Group of Type Windsor-Horton District, North Scotia. Mem. geol. Surv. Can. 314.

Boureau, E. 1975. Traité de Paléobotanique. Paris: Masson.

Dawson, J.W. 1866. On the conditions of the deposition of coal more especially as illustrated by the coal-formation of Nova Scotia and New Brunswick. Q. Jl geol. Soc. Lond. 22, 95-169. 
Dawson, J. W. 1873. Report on the fossil plants of the Lower Carboniferous and Millstone Grit formations of Canada. Geol. Surv. Can.

Miller, H. 1857. The Testimony of the Rocks; or, Geology in its Bearings on the Two Theologies, Natural and Revealed. Edinburgh: Constable, Shepherd and Elliot.

O'Kelly, J. 1862. Explanations to accompany sheet 127 of the maps of the Geological Survey of Ireland illustrating a portion of the Queen's County. Mem. geol. Surv. Ireland.

Read, C. B. 1965. Floras of the Pocono Formation and Price Sandstone in parts of Pennsylvania, Maryland, West Virginia and Virginia. Prof. Pap. U.S. geol. Surv. 263.

Russell, R. J. 1967. River and delta morphology. Coastal Studies Institute, Louisiana State University, Tech. Rep. 52.

\section{J. FEEHAN}

Department of Geology

Trinity College

Dublin, Ireland

30 June 1978

\section{EXPLANATION OF PLATE}

Plate 1(a-f). Aneimites obtusilobus from the Old Red Sandstone of Slieve Bloom, County Offaly, Eire.

Scale in all photographs $1 \mathrm{~cm}$. 
Geol. Mag. Vol. 116, 1979, Feehan, Plate 1, facing page 404.
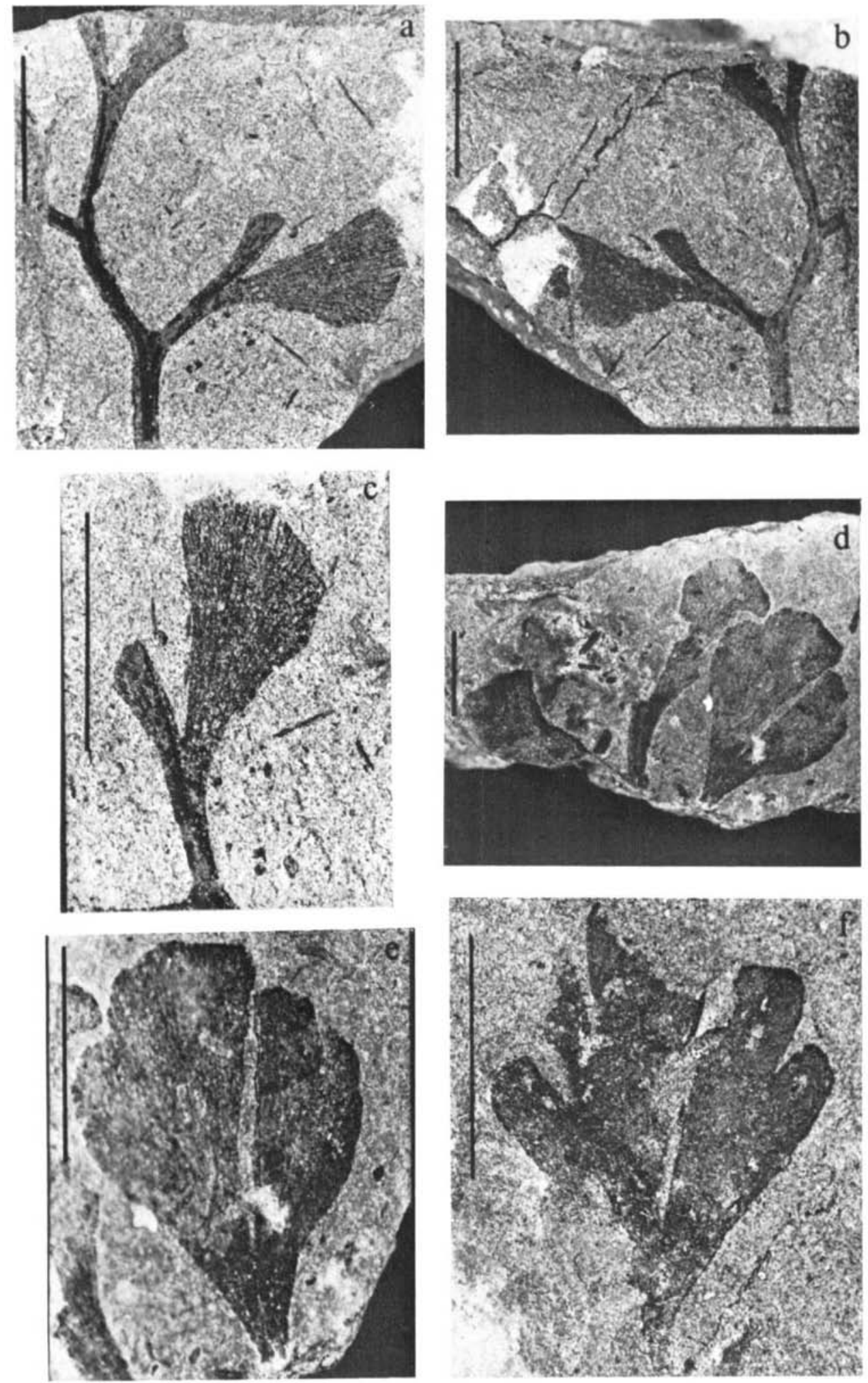

Plate 1. Aneimites obtusilobus from Slieve Bloom, Eire. 